\title{
ANALISIS PENDAPATAN DAN PERSEPSI PETERNAK PLASMA TERHADAP KONTRAK PERJANJIAN POLA KEMITRAAN AYAM PEDAGING DI PROPINSI LAMPUNG
}

\section{THE ANALYSIS OF PLASMA FARMER'S INCOME AND PERCEPTION ON PARTNERSHIP OF BROILER CONTRACT FARMING AT LAMPUNG PROVINCE}

\author{
Yulien Tika Fitriza, F. Trisakti Haryadi*, dan Suci Paramitasari Syahlani \\ Fakultas Peternakan, Universitas Gadjah Mada, Jl. Fauna No. 3, Bulaksumur, Yogyakarta, 55281
}

\section{INTISARI}

\begin{abstract}
Kemitraan usaha ayam pedaging telah berkembang pesat di Indonesia, hal ini memberikan keuntungan yang cukup tinggi bagi peternak. Penelitian ini bertujuan untuk menganalisis pendapatan peternak plasma, menganalisis pengaruh karakteristik peternak plasma terhadap persepsi peternak tentang kontrak perjanjian serta menganalisis hubungan antara persepsi peternak plasma tentang kontrak perjanjian dengan pendapatan peternak plasma. Materi yang digunakan dalam penelitian adalah PT. Sinar Ternak Sejahtera (STS) sebagai inti dan peternak plasma ayam pedaging yang mengikuti pola kemitraan PT. STS berjumlah 34 responden. Pengumpulan data dilakukan melalui teknik wawancara langsung dengan berpedoman pada kuesioner yang telah diuji validitas maupun reliabilitasnya. Analisis data yang digunakan adalah analisis pendapatan, analisis regresi dan analisis korelasi. Hasil penelitian menunjukkan bahwa pendapatan plasma sebesar Rp. 1.590,54 per ekor/periode. Karakteristik umur peternak dan pengalaman beternak tidak berpengaruh nyata $(\mathrm{P}>0,05)$ terhadap persepsi peternak plasma tentang kontrak perjanjian pola kemitraan. Tingkat pendidikan dan jumlah ternak berpengaruh nyata $(\mathrm{P}<0,05)$ terhadap persepsi peternak plasma tentang kontrak perjanjian pola kemitraan. Kesimpulan dalam penelitian ini adalah bahwa pendapatan plasma sebesar Rp. 1.590,54 per ekor/periode. Karakteristik tingkat pendidikan dan jumlah ternak yang positif meningkat artinya semakin tinggi tingkat pendidikan dan jumlah ternak maka semakin baik persepsi peternak plasma tentang kontrak perjanjian. Persepsi peternak terhadap kontrak perjanjian tidak berhubungan secara nyata dengan pendapatan peternak plasma.
\end{abstract}

(Kata kunci: Pendapatan, Persepsi, Kontrak perjanjian, Plasma)

\section{ABSTRACT}

The partnership of broiler contract farming is widespread in Indonesia. This due to highly profitable for farmers. The study was aimed to analysis the income of plasma, to examine the effect of the plasma farmer's characteristics on the farmer's perception of the agreement of contract farming and to analyze the relationship between plasma farmer perception to the contract agreement and the income of plasma. PT. Sinar Ternak Sejahtera (STS) as the integrator was observed and farmers who participated in the partnership pattern of PT. STS were identified as of 34 respondents. Data were collected by direct interview using questionnaires that had been tested for its validity and reliability. Income analysis, regression and correlation analysis were used in this study. Results showed that the plasma farmer's income was $R p$ 1,590,54 per head/period. The age of farmer and raising experience did not significantly influence $(P>0.05)$ the perception of the agreement of contract farming. The education level and the number of broilers significantly influenced $(P<0.05)$ on the plasma farmer's perception to the partnership models of the contract. It can be concluded that the plasma farmer's income was Rp. 1,590,54 per head/period. The education level and the number of broilers raised had effect by meant the higher of education level and the more of total number broilers raised were better improved the plasma farmer's perception to the contract. The farmer's perception of the contract had not significantly related with the income of the plasma.

(Key words: Income, Perception, Contract farming, Plasma farmer)

\footnotetext{
* Korespondensi (corresponding author):

Telp. +628157950789

E-mail: terisakti@yahoo.com
} 


\section{Pendahuluan}

Peternakan ayam pedaging di Indonesia dimulai sejak masa orde lama tahun 1960, berlanjut dari awal orde baru tahun 1970 sampai masa pelita II (1974-1979) yang merupakan tahap pertumbuhan ekonomi nasional. Dunia perunggasan yang semakin populer di kalangan masyarakat dengan skala usaha rumah tangga terus berkembang di berbagai daerah, sementara itu usaha skala besar juga tumbuh dan mampu menjalankan usahanya lebih efisien.

Usaha skala besar inilah pemicu persaingan pasar sehingga usaha ternak besar menguasai harga pasar dan skala kecil atau peternak rakyat menjual hasil ternaknya dengan harga di bawah biaya produksi, peternak juga kesulitan memperoleh bibit ayam yang bermutu, akibatnya peternak rakyat banyak yang gulung tikar. Untuk membantu peternak dalam mengatasi permasalahan tersebut, maka pemerintah melalui UU No. 18 tahun 2009 tentang Peternakan dan Kesehatan Hewan, pasal 30 menganjurkan peternak untuk melakukan kerjasama dengan pihak lain terutama dalam bidang penanaman modal (Anonimus, 2009). Usaha pembinaan yang dilakukan pemerintah untuk memberdayakan peternak antara lain melalui pengembangan pola kemitraan perusahaan dengan peternak kecil. Hal ini disebutkan pula dalam UU No. 18 pasal 31 ayat 1 bahwa peternak dapat melakukan kemitraan usaha di bidang budidaya ternak berdasarkan perjanjian yang saling menguntungkan dan berkeadilan. Lebih jauh dijabarkan pada ayat 2 UU No. 18 tahun 2009 bahwa kemitraan usaha dapat dilakukan dengan perusahaan peternakan.

Tujuan pembangunan dari pemberdayaan usaha peternakan rakyat adalah meningkatkan kesejahteraan masyarakat yang dicerminkan dengan meningkatkan taraf hidup. Peningkatan taraf hidup peternak rakyat di Propinsi Lampung salah satunya dilakukan dengan membentuk pola kemitraan atau Perusahaan Inti Rakyat (PIR). Terdapat lima perusahaan yang menjadi inti pada pola kemitraan ayam pedaging yaitu, PT. Sinar Ternak Sejahtera, PT. Pratama Karya Persada, PT. Ciomas Adisatwa, PT. Janu-putro, PT. Ramajaya (Dinas Peternakan Propinsi Lampung, 2006).

Kemitraan adalah suatu strategi bisnis yang dilakukan oleh dua pihak atau lebih dalam jangka waktu tertentu untuk meraih keuntungan bersama dengan prinsip saling menguntungkan dan saling memberikan manfaat antara pihak yang bermitra. Pola kemitraan di bidang peternakan, adalah salah satu jalan kerjasama antara peternak kecil (plasma) dengan perusahaan swasta dan pemerintah sebagai inti (Hafsah, 2000).
Suharti (2003), menyatakan bahwa model kemitraan yang dilakukan oleh inti adalah melalui penyediaan sarana produksi peternakan, bimbingan teknis dan manajemen, menampung serta memasarkan hasil produksi. Peternak plasma menyediakan kandang, melakukan kegiatan budidaya dan hasil dari penjualan ayam diserahkan kepada pihak inti dengan harga yang telah disesuaikan pada isi kontrak perjanjian kerjasama.

Permasalahan dalam model kemitraan sering menyebabkan keluhan dan kecurigaan yang menimbulkan perdebatan. Pengembangan sebuah pola kemitraan didasarkan pada visi dan misi yang dibentuk dari persepsi inti (perusahaan) terhadap kemitraan yang tercermin dalam kontrak perjanjian yang telah dibuat dengan mempertimbangkan resiko yang akan dihadapi oleh inti. Persepsi peternak plasma yang terdiri dari berbagai skala usaha terhadap kontrak perjanjian dapat berbeda-beda. Berdasarkan pemikiran di atas penulis tertarik mengadakan penelitian tentang analisis pendapatan dan persepsi peternak terhadap kontrak perjanjian kemitraan di Propinsi Lampung.

Penelitian bertujuan untuk menganalisis pendapatan peternak plasma, menganalisis pengaruh karakteristik peternak plasma terhadap persepsi tentang kontrak perjanjian, dan menganalisis hubungan antara persepsi peternak plasma tentang kontrak perjanjian dengan pendapatan peternak plasma.

\section{Materi dan Metode}

\section{Materi}

Penelitian ini merupakan studi kasus pada pola kemitraan yang ada di PT. Sinar Ternak Sejahtera (STS) Propinsi Lampung. Materi yang digunakan dalam penelitian adalah PT. STS sebagai inti dan peternak plasma ayam pedaging yang mengikuti pola kemitraan PT. STS. Peternak plasma yang digunakan dalam penelitian ini berjumlah 34 responden.

\section{Metode}

Penentuan sampel peternak plasma dilakukan secara purposive sampling method. Responden dipilih berdasarkan data sekunder dari inti dan informasi dari peternak. Peternak plasma yang dipilih adalah peternak yang telah memelihara ayam pedaging selama 5 periode berurutan selama satu tahun.

\section{Analisis data}

Untuk mengungkap persepsi peternak terhadap perjanjian kemitraan maka diajukan daftar pertanyaan yang mempunyai alternatif jawaban sangat setuju, setuju, ragu-ragu, tidak setuju, sangat 
tidak setuju dengan masing-masing diberi skor menurut skala Likert. Pertanyaan positif berturutturut mempunyai skor 5, 4, 3, 2, 1 dan pertanyaan negatif diberi skor sebaliknya (Singarimbun dan Effendi, 1989). Analisis pendapatan dari usaha peternakan ayam pedaging dihitung berdasarkan selisih antara total penerimaan dengan total biaya (Soekartawi, 1989).

Rumus yang digunakan: $\mathrm{Pd}=\mathrm{TR}-\mathrm{TC}$

Keterangan:

$$
\mathrm{TC}=\mathrm{FC}+\mathrm{VC}
$$

$\mathrm{Pd}$ : pendapatan $(\mathrm{Rp} /$ periode $)$

$\mathrm{FC}$ : biaya tetap (Rp/periode)

$\mathrm{VC}$ : biaya tidak tetap (Rp/periode)

$\mathrm{TC}:$ total biaya $(\mathrm{Rp} /$ periode $)$

$\mathrm{TR}$ : total penerimaan $(\mathrm{Rp} /$ periode $)$

Analisis regresi berganda digunakan untuk mengetahui adanya pengaruh karakteristik peternak yang terdiri dari 1) umur peternak, 2) tingkat pendidikan, 3) pengalaman berternak, dan 4) jumlah ternak terhadap persepsi peternak plasma tentang kontrak perjanjian. Model regresi pada penelitian ini adalah: $\mathbf{Y}=\boldsymbol{\beta}_{0}+\boldsymbol{\beta}_{1} \mathbf{X}_{1}+\boldsymbol{\beta}_{2} \mathbf{X}_{2}+\boldsymbol{\beta}_{3} \mathbf{X}_{3}+\boldsymbol{\beta}_{4} \mathbf{X}_{4}+\boldsymbol{e}$ Keterangan:

$\mathrm{X}_{1} \quad$ : variabel umur peternak (thn)

$\mathrm{X}_{2} \quad$ : variabel tingkat pendidikan (thn)

$\mathrm{X}_{3} \quad$ : variabel pengalaman (thn)

$\mathrm{X}_{4} \quad$ : variabel jumlah ternak (ekor/periode)

$\mathrm{Y} \quad$ : variabel persepsi peternak tentang

kontrak perjanjian (skor)

$\beta_{0} \quad:$ konstanta

$\beta_{\mathrm{n}=1,2,3,4} \quad$ : parameter estimasi

e : kesalahan (error)

Untuk mengetahui hubungan antara persepsi peternak plasma tentang kontrak perjanjian dengan pendapatan peternak plasma digunakan analisis korelasi. Rumus koefisien korelasi adalah sebagai berikut (Saleh, 2004):

$$
r=\frac{\left[n \sum X Y\right]-\left[\sum X \mathrm{I} \sum Y\right]}{\sqrt{\left[n \sum X^{2}-\left(\sum X\right)^{2}\left[n \sum Y^{2}-\left(\sum Y\right)^{2}\right]\right.}}
$$

Keterangan:

$r \quad$ : koefisien korelasi

$Y \quad$ : pendapatan peternak plasma

$X$ : persepsi peternak plasma terhadap kontrak perjanjian (skor)

$n \quad$ : jumlah observasi

\section{Hasil dan Pembahasan}

\section{Karakteristik peternak}

Karakteristik responden dalam penelitian meliputi umur, tingkat pendidikan, pengalaman beternak dan jumlah ternak. Uraian tentang karakteristik responden tersaji pada Tabel 1 .

Rerata umur responden dalam penelitian ini adalah 43,32 tahun (Tabel 1). Umur tertinggi responden yaitu 55 tahun dan umur terendah responden adalah 30 tahun. Umur responden rerata berada pada usia produktif. Batas umur produktif di negara Indonesia pada kelompok umur 15-64 tahun (Mantra, 2003).

Pendidikan responden tertinggi adalah Sekolah Menengah Atas (SMA) dan terendah Sekolah Dasar (SD). Tinggi rendahnya responden dari hasil penelitian mempunyai distribusi tingkat pendidikan sebagian besar SMA yaitu sebanyak $63,75 \%$, kemudian berurutan diikuti SMP sebanyak $30,00 \%$ dan SD sebesar 6,25\% (Tabel 1). Tinggi pendidikan yang ditempuh oleh peternak akan berkaitan dengan tingkat kemampuan mereka dalam menyerap pengetahuan yang diberikan. Usaha peternakan ayam sebagian besar dilakukan relatif lama yaitu berkisar antara 5-10 tahun dengan nilai rerata 6,01 tahun. Umumnya pengalaman beternak berkorelasi positif dengan sikap kritis dan hati-hati. Rerata jumlah ternak yang dimiliki oleh responden adalah 7.090 ekor (Tabel 1). Skala usaha peternakan ayam menentukan besarnya pendapatan dan keuntungan pelaku usaha.

Tabel 1. Karakteristik responden (respondent's characteristics)

\begin{tabular}{lc}
\hline \hline \multicolumn{1}{c}{ Karakteristik responden (respondent's characteristics) } & Nilai (value) \\
\hline Rerata umur (thn) (average of age (year)) & 43,32 \\
Tingkat pendidikan (\%) (level of education (\%)) & 6,25 \\
SD (elementary school) & 30,00 \\
SMP (junior high school) & 63,75 \\
SMA (senior high school) & 6,01 \\
Rerata pengalaman beternak (thn) (average of farming experience (year)) & 7,09 \\
Rerata jumlah ternak (000 ekor/periode) (average number of broiler & \\
(head/period) & \\
\hline
\end{tabular}




\section{Analisis pendapatan peternak plasma}

Keberhasilan besar-kecilnya produksi yang diperoleh dalam usaha agribisnis ditentukan oleh ketersediaan faktor produksi atau input. Faktor yang menentukan keberhasilan suatu usaha yaitu faktor lahan, modal untuk membeli bibit, obat-obatan, tenaga kerja dan aspek manajemen (Soekartawi, 1989).

Tabel 2 terlihat bahwa biaya tetap terdiri dari listrik, sewa tanah, penyusutan kandang dan peralatan. Biaya tidak tetap pemanas, sekam, upah tenaga kerja dan perawatan kandang. Biaya tidak tetap selalu berubah-ubah sehingga mengakibatkan biaya operasionalnya meningkat dan biaya tidak tetap terkecil adalah untuk perawatan kandang.

Biaya tetap adalah biaya yang tidak terpengaruh oleh perubahan tingkat kegiatan maupun volume output. Rerata biaya listrik yang dikeluarkan plasma dalam 5 periode sebesar $20,45 \%$ dari biaya tetap dengan biaya Rp. $902.824,53$ per periode. Dalam penelitian ini listrik lebih banyak digunakan untuk penerangan kandang, sedangkan untuk pemanas menggunakan gas. Rerata sewa tanah tiap plasma 39,96\% dari biaya tetap dengan biaya sebesar Rp. 1.763.917,59 per periode. Biaya tidak tetap adalah sifatnya berubah-ubah secara proporsional terhadap perubahan output. Rerata biaya pemanas yang digunakan peternak plasma dalam pemeliharaan $18,83 \%$ dari biaya tidak tetap dengan biaya sebesar Rp. 568.276,47 per periode. Rerata perawatan kandang yang dikeluarkan plasma adalah 24,43\% dengan biaya sebesar Rp. 73.382,35 per periode.

\section{Penerimaan dan pendapatan}

Penerimaan peternak plasma ayam pedaging terdiri dari hasil penjualan ayam hidup, kotoran sebagai pupuk, karung pakan dan kompensasi pemeliharaan apabila produk yang dihasilkan lebih baik seperti bonus FCR dan bonus mortalitas (Tabel 3).

Penerimaan peternak dalam satu tahun (lima periode) terdiri dari penjualan ayam, penjulan karung, bonus FCR dan mortalitas. Hal ini sesuai dengan pendapat Iskandar (1993), menyatakan bahwa penerimaan dalam peternakan ayam pedaging antara lain bersumber dari penjualan ayam, penjualan karung pakan dan nilai kotoran ayam yang dihasilkan. Tabel 4 menunjukkan rerata penerimaan, biaya produksi dari inti dan biaya produksi dari peternak plasma per periode. Penerimaan peternak plasma sebesar Rp. 109.498.772,34. Biaya produksi peternak plasma sebesar Rp. 7.432.773,53 per periode yang terdiri dari biaya tetap dan biaya tidak tetap. Biaya produksi dari inti sebesar Rp. 98.222.017,58. Pada Tabel 4 terlihat bahwa rerata

Tabel 2. Biaya rerata peternak plasma per periode selama 1 tahun (average cost of plasma farmers per period in one year)

\begin{tabular}{lrr}
\hline \multicolumn{1}{c}{ Biaya $($ cost $)$} & Nilai (Rp) (value $(\mathrm{Rp})$ & \multicolumn{1}{c}{$\%$} \\
\hline Biaya tetap (fixed cost): & & \\
- Listrik (electricity) & $902.824,53$ & 20,45 \\
- Sewa tanah (ground rent) & $1.763 .971,59$ & 39,96 \\
- Penyusutan kandang dan peralatan (cages and equipment depreciation) & $1.747 .556,88$ & 39,59 \\
Total (a) & $4.414 .350,00$ & 100,00 \\
Biaya tidak tetap (variable cost): & $568.276,47$ & \\
- Pemanas (heating) & $751.176,47$ & 24,83 \\
- Sekam (husk) & $1.625 .588,24$ & 53,86 \\
- Upah tenaga kerja (labor cost) & $73.382,35$ & 24,43 \\
- Perawatan kandang (housing maintenance) & $3.018 .423,53$ & 100,00 \\
Total (b) & $7.432 .773,53$ & \\
Total biaya (a+b) (total cost (a+b)) &
\end{tabular}

Keterangan: 5 periode/tahun $(\bar{X}: 7.090$ ekor) (5 period/year $(\bar{X}: 7.090$ head)).

Tabel 3. Macam penerimaan dan rerata total penerimaan peternak plasma per periode selama 1 tahun (kinds of revenue and the average of total revenue of plasma per period in one year)

\begin{tabular}{lcc}
\hline \hline \multicolumn{1}{c}{ Macam penerimaan (kinds of revenue) } & Nilai (Rp) (value $(\mathrm{Rp}))$ & \multicolumn{1}{c}{$\%$} \\
\hline Penjualan ayam (chicken sales) & $112.665 .410,65$ & 96,79 \\
Penjualan karung (sale of sacks) & $1.832 .470,59$ & 1,57 \\
Bonus FCR (FCR bonus) & $1.565 .586,63$ & 1,34 \\
Bonus mortalitas (mortality bonus) & $339.806,83$ & 0,29 \\
Total penerimaan (total revenue) & $116.403 .304,70$ & 100,00 \\
\hline
\end{tabular}

Keterangan: 5 periode/tahun $(\mathrm{X}: 7.090$ ekor) (5 period/year $(\mathrm{X}: 7.090$ head)). 
Tabel 4. Rerata penerimaan, biaya produksi dari inti dan biaya produksi dari peternak plasma per periode selama 1 tahun (average revenues, production cost of core and the production costs of plasma farmers per period in one year)

\begin{tabular}{lc}
\hline \hline \multicolumn{1}{c}{ Uraian (description) } & Nilai (Rp) (value (Rp) $)$ \\
\hline Penerimaan (revenue) (a) & $109.498 .772,34$ \\
Biaya produksi dari plasma (production cost of plasma) (b) & $7.432 .773,53$ \\
Biaya produksi dari inti (production cost of core): & \\
- DOC & $23.669 .705,74$ \\
- Pakan (feed) & $71.346 .679,23$ \\
- Obat-obatan (drugs) & $3.205 .631,61$ \\
Total (c) & $98.222 .017,58$ \\
Residual/keuntungan (a-b-c) & $11.276 .456,76$ \\
(Rp/ekor) (Rp/head) & $1.590,54$ \\
\hline
\end{tabular}

Keterangan: 5 periode/tahun $\overline{\overline{\mathrm{X}}}: 7.090$ ekor) (5 period/year $\overline{\overline{\mathrm{X}}}: 7.090$ head)).

biaya pakan yang dikeluarkan oleh peternak plasma sebesar Rp. 71.346.679,23 per periode. Pakan merupakan biaya terbesar dari semua biaya produksi yang dikeluarkan oleh plasma.

Anggorodi (1985), menyatakan biaya pakan $60-70 \%$ dari biaya produksi. Rasyaf (1994), menyatakan bahwa biaya pakan mencapai $40-75 \%$ dari total biaya tidak tetap. Hambatan utama dari faktor pakan adalah harga, penyediaan dan distribusi yang tidak merata, yang menyebabkan peternak mengalami ketidakpastian dalam penerimaan laba. Prawirokusumo dan Nasroedin (1979), menyatakan bahwa harga pakan yang mahal merupakan suatu hambatan usaha peternakan ayam, terutama peternak kecil.

Biaya terbesar setelah pakan adalah biaya bibit (DOC), hal ini sesuai dengan pendapat Sulistyono (1995), bahwa biaya terbesar setelah pakan adalah DOC sebesar $27 \%$ dari total biaya sedangkan menurut Siregar dan Ilham (2003), biaya DOC $20 \%$ dan $19,2 \%$ dari total biaya (Prawirokusumo, 1990). Rerata peternak plasma memiliki jumlah ternak sebesar 7.090 ekor ayam (Tabel 4). Rerata pendapatan selama per periode sebesar Rp. 11.276.456,76, sehingga pendapatan peternak untuk per ekor ayam sebesar Rp. 1.590,54 ekor/periode (Tabel 4).

\section{Pengaruh karakteristik peternak terhadap persepsi peternak tentang kontrak perjanjian}

Pengaruh karakteristik peternak yang terdiri dari umur peternak, tingkat pendidikan, pengalaman beternak dan jumlah ternak terhadap persepsi peternak plasma tentang kontrak perjanjian pola kemitraan dievaluasi melalui pengujian regresi linier berganda yang hasilnya tersaji pada Tabel 5 .

Berdasarkan hasil statistik pengujian regresi pengaruh karakteristik peternak plasma terhadap kontrak perjanjian diperoleh $\mathrm{F}$ hitung 3,080
$(\mathrm{P}<0,05)$. Umur peternak, tingkat pendidikan, pengalaman berternak dan jumlah ternak berpengaruh secara nyata dengan koefisien determinasi $\left(\mathrm{R}^{2}\right)$ yaitu sebesar 0,298 atau $29,8 \%$. Hal ini dikarenakan besarnya pengaruh karakteristik peternak terhadap persepsi kontrak perjanjian ditentukan bersama-sama oleh faktor umur peternak, tingkat pendidikan, pengalaman beternak dan jumlah ternak sebesar $29,8 \%$ dan $70,2 \%$ oleh faktor lain yang tidak dimasukkan ke dalam model ini. Model persamaan regresi dari faktor-faktor di atas adalah $\mathrm{Y}=1,7572+0,0177 \mathrm{X}_{1}+0,2588 \mathrm{X}_{2}+0,0269 \mathrm{X}_{3}+$ $0,00005281 \mathrm{X}_{4}$.

\section{Umur peternak}

Dari Tabel 5 dapat diketahui bahwa hasil pengujian terhadap tingkat umur peternak tidak berpengaruh nyata terhadap persepsi dengan koefisien regresi sebesar 0,0177 ( $P>0,05)$. Hal ini disebabkan oleh tingkat umur peternak relatif sama yaitu rerata 43,32 tahun. Umur peternak berada pada usia produktif, seharusnya lebih bisa optimal dalam pemahaman tentang isi kontrak perjanjian. Hal ini tidak sesuai dengan pernyataan Soekartawi (2005), bahwa usia produktif peternak akan lebih optimal dalam mengelola usaha peternakannya sehingga dimungkinkan adanya peningkatan produktifitas dan pendapatan. Ditambahkan Mardikanto (1993) yang menyatakan bahwa umur merupakan salah satu faktor utama yang mempengaruhi efisiensi belajar dan semakin tua (di atas 50 tahun) biasanya hanya melaksanakan kegiatan-kegiatan yang sudah biasa ditetapkan oleh warga masyarakat setempat. Umur peternak dalam penelitian ini berada pada usia produktif namun tidak optimal dalam pemahaman tentang kontrak perjanjian yang disebabkan dalam kesehariannya hanya melakukan kegiatan-kegiatan atau kebiasaan-kebiasaan yang ada. 
Tabel 5. Pengaruh karakteristik peternak terhadap persepsi tentang kontrak perjanjian (farmer's characteristics influence on the farmer's perception of the contract agreement)

\begin{tabular}{lcc}
\hline \hline \multicolumn{1}{c}{ Variabel independen (independent variable) } & Koefisien & p.value \\
\hline Konstanta $($ constanta) & 1,7572 & $0,020^{*}$ \\
Umur peternak $($ breeder age $)\left(\mathrm{X}_{1}\right)$ & 0,0177 & 0,107 \\
Tingkat pendidikan $($ level of education $)\left(\mathrm{X}_{2}\right)$ & 0,2588 & $0,013^{*}$ \\
Pengalaman beternak (raising experience) $\left(\mathrm{X}_{3}\right)$ & 0,0269 & 0,532 \\
Jumlah ternak (number of livestock) $\left(\mathrm{X}_{4}\right)$ & 0,00005281 & $0,012^{*}$ \\
$\mathrm{R}^{2}=0,298$ & F-hitung $=3,080$ & $0,031^{*}$ \\
\hline
\end{tabular}

$* \mathrm{P}<0,05$.

\section{Tingkat pendidikan}

Tingkat pendidikan memberikan pengaruh nyata $(\mathrm{P}<0,05)$ terhadap persepsi peternak tentang kontrak perjanjian pola kemitraan sebesar 0,2588 (bertanda positif) artinya semakin tinggi tingkat pendidikan peternak, dapat meningkatkan persepsi peternak tentang kontrak perjanjian pola kemitraan. Pendidikan tinggi akan mudah untuk memahami kontrak perjanjian dalam suatu kemitraan. Sesuai pernyataan Padmowihardjo (1994), bahwa tingginya tingkat pendidikan akan menentukan besarnya kemampuan belajar seseorang. Semakin tinggi tingkat pendidikan seseorang maka akan semakin terlatih dirinya untuk belajar dan semakin banyak "trik-trik" belajar yang mereka miliki sehingga semakin besar kemampuan belajarnya. Ditambahkan Sunarto (2006), bahwa pendidikan merupakan suatu indikasi yang sangat penting dalam menilai suatu keberhasilan usaha, karena dengan tingkat pendidikan seseorang akan lebih mudah untuk mengadopsi ilmu dan teknologi secara lebih optimal, sehingga dapat diterapkan dalam usaha yang lebih baik.

\section{Pengalaman beternak}

Pengalaman beternak tidak berpengaruh signifikan terhadap kontrak perjanjian pola kemitraan. Hal ini disebabkan karena pengalaman beternak yang dilakukan secara turun-temurun mengakibatkan peternak plasma kurang memperhatikan aspek usaha terutama keuntungan dari segi ekonomi. Hal ini sesuai pendapat Syafrudin (2003) bahwa pengalaman beternak tidak menjamin adanya pengaruh dalam beternak. Selain itu pengalaman beternak biasanya diperoleh secara turun-temurun dari pendahulu (Mustofa, 2005).

Haryadi (1997), menyatakan bahwa umumnya pengalaman beternak akan menghasilkan suatu kebiasaan yang mempengaruhi peternak dalam pola pemeliharaan. Faktor kebiasaan peternak secara turun-temurun masih terus dilaksanakan, walaupun sebenarnya sudah mengetahui anjuran-anjuran yang seharusnya dilaksanakan. Kebiasaan-kebiasaan yang kurang sesuai dengan anjuran yang masih diterapkan tersebut tentu akan mempengaruhi responden dalam beternak, sehingga pola pemeliharaan menjadi kurang berkembang ke arah yang lebih baik.

\section{Jumlah ternak}

Jumlah ternak memberikan pengaruh nyata $(\mathrm{P}<0,05)$ terhadap persepsi peternak tentang kontrak perjanjian pola kemitraan sebesar 0,0005281 (bertanda positif) artinya semakin banyak jumlah ternak dapat meningkatkan persepsi peternak tentang kontrak perjanjian pola kemitraan. Gusasi dan Saade (2006), menyatakan besarnya jumlah ternak ayam pedaging yang dipelihara menentukan besarnya pendapatan dan keuntungan pelaku usaha peternakan ayam pedaging, yang skala usahanya semakin besar maka tingkat pendapatan dan efisiensi semakin tinggi. Tingkat pendapatan yang diperoleh peternak plasma ayam pedaging akan semakin meningkat seiring dengan peningkatan jumlah ternak ayam pedaging (Purwanto, 1999).

\section{Hubungan antara persepsi peternak plasma tentang kontrak perjanjian dengan pendapatan peternak plasma}

Pengembangan ayam pedaging melalui pola kemitraan terdapat suatu kerjasama yang berkaitan dengan kontrak perjanjian isinya penyediaan sapronak, penentuan harga, jaminan dan resiko yang telah disepakati antara dua belah pihak.

Hasil pengujian terhadap penyediaan sapronak tidak ada hubungan yang nyata $(\mathrm{P}>0,05)$ dengan pendapatan peternak plasma. Korelasi sebesar $-0,036$, yang artinya penyediaan sapronak yang disediakan oleh inti dalam kontrak perjanjian tidak ada hubungannya dengan pendapatan peternak plasma. Isi dari kontrak perjanjian tentang penyediaan sapronak berupa DOC, pakan, dan obatobatan yang merupakan tujuan dari kemitraan. Inti juga berperan sebagai koordinator pembinaan namun, hasil dari penelitian ini tidak menunjukkan ada hubungan persepsi peternak tentang penyediaan sapronak dengan pendapatan peternak plasma karena pada dasarnya peternak hanya sekedar menerima segala sesuatu yang disediakan oleh inti. 
Persepsi peternak pada variabel penentuan harga dalam kontrak perjanjian tidak ada hubungan yang nyata $(\mathrm{P}>0,05)$ dengan pendapatan peternak plasma. Korelasi sebesar -0,063 yang artinya penentuan harga yang disediakan oleh inti dalam kontrak perjanjian tidak ada hubungannya dengan pendapatan peternak plasma. Variabel penentuan harga berisi tentang harga bibit DOC, harga pakan, harga obat-obatan, harga panen sampai harga bonus FCR dan mortalitas yang telah disepakati bersama dalam kontrak perjanjian pola kemitraan ayam pedaging. Peternak plasma dapat meningkatkan pendapatan dengan mencapai bonus FCR dan mortalitas namun peternak plasma hanya melakukan pemeliharaan dan kebiasaan-kebiasaan yang ada.

Andi (2009) menyatakan bahwa peternak melakukan pemeliharaan dengan kebiasaan keluarga yang sifatnya turun-temurun dari generasi ke generasi. Lebih lanjut dinyatakan bahwa peternak seakan tidak mau meninggalkan 'warisan keluarga' ini walaupun mereka harus memeliharanya dalam jumlah yang sangat sedikit. Terlalu sering peternak mengalami kerugian karena secara perhitungan ekonomi usaha yang mereka lakukan tidak menghasilkan laba (Andi, 2009). Persepsi peternak pada variabel jaminan dalam kontrak perjanjian diketahui hasilnya tidak ada hubungan yang nyata $(\mathrm{P}>0,05)$ dengan pendapatan peternak plasma. Korelasi sebesar 0,078 , yang artinya jaminan yang disediakan oleh inti dalam kontrak perjanjian tidak ada hubungannya dengan pendapatan peternak plasma. Variabel jaminan berisi tentang penyerahan surat tanah "Girik atau sertifikat", membayar uang tunai dan menyerahkan akta jual beli tanah. Begitu juga dengan hasil dari variabel resiko tidak ada hubungan yang nyata $(\mathrm{P}>0,05)$ dengan pendapatan peternak plasma. Korelasi sebesar 0,124 yang artinya resiko yang disediakan oleh inti dalam kontrak perjanjian tidak ada hubungannya dengan pendapatan peternak plasma.

Hubungan tidak signifikan juga terjadi antara aspek persepsi dengan pendapatan peternak plasma $(\mathrm{P}>0,05)$. Hal ini disebabkan karena keseluruhan kontrak perjanjian yang dilakukan telah disepakati bersama baik dalam penyediaan sapronak, penentuan harga, jaminan dan resiko. Ditambahkan Syafrudin (2003) yang menyatakan bahwa pemeliharaan beternak bersumber dari informasi yang hanya didapat dari membaca koran, melihat TV, mendengar radio, dan mendengar penyuluhan tetapi tidak mendalami atau menelaah isinya. Penambahan sumber informasi yang didapat peternak tidak akan menambah pengetahuan terhadap pemahaman kontrak perjanjian. Anonimus (2001), menyatakan bahwa merencanakan peternakan dimulai dari diri peternak yang akan mengelola peternakan, baik langsung maupun tidak langsung sekalipun sebagai penyandang dana atau terkait dengan modal. Usaha ayam pedaging yang dijalankan juga harus memperhitungkan adanya faktor resiko antara lain serangan penyakit yang menyebabkan besarnya tingkat mortalitas, manajemen yang tidak efisien atau rendahnya harga jual sehingga keuntungan yang diperoleh sangat kecil yang mengakibatkan usaha tersebut tidak dapat berkelanjutan.

Berdasarkan hasil dari korelasi antara persepsi peternak dengan pendapatan peternak plasma, dalam kumpulan variabel penyediaan sapronak, penentuan harga, jaminan dan resiko menunjukkan bahwa tidak ada hubungan antara persepsi peternak dengan pendapatan peternak plasma. Hal yang diduga dapat mempengaruhi pendapatan adalah manajemen pemeliharaan peternak dan bimbingan dari inti yang dapat membantu peternak dalam pemeliharaan.

Susilawati (1998), menyatakan bahwa pendapatan peternak dipengaruhi oleh manajemen pemeliharaan oleh peternak itu sendiri dan mendapatkan bimbingan teknisi dari inti. Ditambahkan Komara (2009), bahwa pendapatan peternak sangat tergantung pada lokasi kandang dan kepemilikan kandang (milik sendiri atau sewa), dan jaminan keamanan di daerah tersebut. Iwansah (2003), menyatakan sistem kerjasama dalam kemitraan harus ada pembagian resiko usaha yang jelas dan proporsional antara inti dan plasma. Hasil penelitian ini menunjukkan bahwa pemahaman peternak plasma tentang kontrak perjanjian tidak ada hubungannya dengan pendapatan peternak plasma.

Tabel 6. Hasil korelasi antara persepsi peternak tentang kontrak perjanjian dan pendapatan peternak plasma (the correlation between the farmer's perception of contract agreement and the plasma farmer's income)

\begin{tabular}{lcc}
\hline \multicolumn{1}{c}{ Variabel (variable) } & Koefisien korelasi (coefficient of correlation) & p.value \\
\hline Penyediaan sapronak (provision of facilities) & 0,098 & 0,583 \\
Penentuan harga (pricing) & 0,181 & 0,306 \\
Jaminan (guarantee) & $-0,027$ & 0,878 \\
Resiko (risk) & $-0,030$ & 0,866 \\
Persepsi kontrak (perception of contract agreement) & 0,112 & 0,527 \\
\hline
\end{tabular}




\section{Kesimpulan dan Saran}

\section{Kesimpulan}

Berdasarkan hasil penelitian dapat diambil kesimpulan bahwa rerata pendapatan peternak plasma yang mengikuti pola kemitraan PT. STS adalah sebesar Rp. 1.590,54 per ekor/periode. Karakteristik tingkat pendidikan peternak plasma yang semakin tinggi mengakibatkan persepsi peternak terhadap kontrak perjanjian akan semakin baik. Persepsi peternak terhadap kontrak perjanjian akan semakin baik dengan semakin besarnya jumlah ternak yang dipelihara. Persepsi peternak terhadap kontrak perjanjian tidak berhubungan secara nyata dengan pendapatan peternak plasma.

\section{Saran}

Berdasarkan hasil penelitian yang telah dilakukan maka penulis menyarankan bahwa untuk dapat meningkatkan persepsi peternak tentang kontrak perjanjian maka PT. Sinar Ternak Sejahtera (STS) perlu melakukan bimbingan dan pendampingan tentang kontrak perjanjian. Pendampingan dan bimbingan intensif diperlukan, khususnya pada peternak yang mempunyai tingkat pendidikan rendah dan jumlah ternak yang relatif sedikit, agar mereka mempunyai pemahaman yang lebih baik tentang kontrak perjanjian yang akan disepakati.

\section{Daftar Pustaka}

Andi. 2009. Usaha Peternakan Domba Rakyat, Upaya Mempertahankan Tradisi. Available at http://www.disnak.jabarprov.go.id/data/arsip/ Intensifikasi\%20Ternak\%20Ayam\%20Buras. pdf. Accession date: 20 Juni 2011.

Anggorodi. 1985. Kemajuan Mutakhir dalam Ilmu Makanan Ternak Unggas. Penerbit UI. Jakarta.

Anonimus. 2001. Setengah Abad Ayam Ras Di Indonesia (1950-2000). Penerbit ASOHI. Jakarta.

Anonimus. 2009. UU RI No.18 Tahun 2009 Tentang Peternakan dan Kesehatan Hewan. Available at http:www.ditjennak.deptan. go.id/download.php. Accession date: 25 Juni 2011.

Dinas Peternakan Propinsi Lampung. 2006. Laporan Tahunan. Bandar Lampung.

Gusasi, A. dan M.A. Saade. 2006. Analisis Pendapatan dan Efisiensi Usaha Ternak Ayam Potong pada Usaha Skala Kecil. Available at http:www.stpp-gowa.ac.id/hinght.download. jurnal/serisosek.Pdf. Accession date: 25 Juni 2011.
Hafsah, J.M. 2000. Kemitraan Usaha Konsep dan Strategi. Cetakan Kedua. PT. Penerbit Swadaya. Jakarta.

Haryadi, F.T. 1997. Efektifitas penyuluhan sapta usaha peternakan sapi potong pada dua model perkampungan ternak. Tesis S-2 Pasca Sarjana. Institut Pertanian Bogor. Bogor.

Iskandar, S.E. 1993. Analisis Ekonomi Tata Niaga Ayam Ras Pedaging pada Perusahaan Kecil di Bogor. BPT Ciawi-Fakultas Peternakan, IPB, Bogor.

Iwansah, D. 2003. Analisis finansial plasma ayam broiler pola peternakan inti rakyat di Kabupaten Sukabumi (studi kasus perusahaan Cimandiri Farm). Skripsi S-1. Fakultas Peternakan Universitas Gadjah Mada. Yogyakarta.

Komara, T. 2009. Teknik Budidaya Ayam Broiler. Available at www.google.http//toni-komara. blogspot.com. Accession date: 4 Juni 2011.

Mantra, I.B. 2003. Demografi Umum. Pustaka Pelajar. Yogyakarta.

Mardikanto, T. 1993. Penyuluhan Pembangunan Pertanian. Sebelas Maret University Press. Surakarta.

Mustofa, M.S. 2005. Kemiskinan Masyarakat Petani di Desa di Jawa. Universitas Negeri Semarang Press. Semarang.

Padmowiharjo, S. 1994. Psikologi Belajar Mengajar. Universitas Terbuka. Jakarta.

Prawirokusumo, S. 1990. Ilmu Usahatani. Edisi ke1. BPFE-UGM, Yogyakarta.

Prawirokusumo, S. dan Nasroedin. 1979. Beberapa Azas Ekonomi Produksi Peternakan. Universitas Gadjah Mada, Yogyakarta.

Purwanto, A.D. 1999. Analisis profitabilitas peternak plasma ayam pedaging pada berbagai tingkat skala usaha melalui perusahaan kemitraan wilayah Kabupaten Tanggamus di Lampung. Tesis S-2. Fakultas Peternakan UGM. Yogyakarta.

Rasyaf, M. 1994. Beternak Ayam Pedaging. Edisi ke-10. Penerbit PT Penebar Swadaya, Jakarta.

Saleh, S. 2004. Statistik Deskriptif. Edisi Revisi. Percetakan AMP YKPN. Yogyakarta.

Singarimbun, M. dan S. Effendi. 1989. Metode Penelitian Survei. Penerbit LP3ES. Jakarta.

Siregar, A.P. dan N. Ilham. 2003. Upaya peningkatan efisiensi usaha ternak ditinjau dari aspek yang berdaya saing. Forum Penelitian Agro Bisnis 21 (1): 57-66.

Soekartawi. 1989. Prinsip Dasar Ekonomi Pertanian Teori dan Aplikasi. Rajawali Press. Jakarta.

Soekartawi. 2005. Prinsip Dasar Komunikasi Pertanian. Penerbit UI Press. Jakarta. 
Suharti. 2003. Analisis profitabilitas usaha ayam pedaging pola kemitraan di Kabupaten Magelang. Tesis S-2. Fakultas Peternakan Universitas Gadjah Mada. Yogyakarta.

Sulistyono. 1995. Menghindari Pemborosan Ransum. Majalah Poultry Indonesia. 85: 20-23.

Sunarto. 2006. Perilaku Konsumen. Amus. Yogyakarta.
Susilawati. 1998. Analisis keuangan plasma broiler suatu pola PIR di Sleman pada situasi krisis moneter. Skripsi S-1. Fakultas Peternakan Universitas Gadjah Mada. Yogyakarta.

Syafrudin. 2003. Pengaruh media cetak brosur dalam proses adopsi dan difusi inovasi beternak ayam broiler di Kota Kendari. Tesis S-2. Fakultas Pertanian. Universitas Gadjah Mada. Yogyakarta. 